\title{
RELIGIOUS MOVEMENTS AND CONGREGATIONS IN WEST ESTONIA FROM THE MID-18th TO THE BEGINNING OF THE 20th CENTURY: THEIR INFLUENCE ON THE ESTONIAN AND ESTONIAN-SWEDISH POPULAR CULTURE
}

\author{
Jaanus PLAAT \\ Department of Ethnology, University of Tartu; Estonian National Museum \\ Veski 32, 51014 Tartu, Estonia
}

\begin{abstract}
From the 16th century, Estonia has been a predominantly Lutheran country. Nevertheless, since the 1740s several religious movements have occurred in Estonia occasionally conflicting with the established Lutheran Church. More serious Christianisation among the Estonians began with the Moravian movement which spread widely in Estonia during the 18th and 19th centuries. The Moravian congregations stayed inside the Lutheran Church. The next influential religious movements in the 19th century were the movement of the Heaven-Travellers and shifting from the Lutheran to the Russian Orthodox Church. After the 1880s, various Protestant congregations sprang up in Estonia and developed into a considerable power alongside the Lutheran and Orthodox Churches. Throughout the period, discussed in this paper (from the 1740s to the beginning of the 20th century), the main centres of the new religious movements have been in the counties of West Estonia inhabited not only by the Estonians, but also by the community of the Estonian Swedes. The paper discusses the religious movements in West Estonia and the influence of these movements on the popular culture of the Estonians and the Estonian Swedes.

Keywords: Estonia, Lutheran Church, Moravian movement, Russian Ortodox Church
\end{abstract}

According to the confession dominating in official religious life, Estonia in the 18th century could be called a Lutheran country. Yet the more serious Christianising of the previously rather formally Christian country-folk was brought about not by the official Lutheran Church, but the religious movement of Brethren congregations spreading within the Lutheran Church. The Brethren movement began to spread wider among the Estonian peasantry in the 1740s, gathering greater momentum in the counties of West Estonia: Saaremaa, Läänemaa and Hiiumaa. The West Estonian counties remained the main centres of the Brethren movement in Estonia in the 19th century, too. In the 1840s, an extensive tendency appeared in Saaremaa to change from Lutheranism to Russian Orthodoxy; in the 1880s, the same trend spread to Läänemaa and Hiiumaa. The movement of religious awakening which began in West Estonia in the last quarter of the 19th century, gave rise to the appearance of new Free Churches in Estonia. Several other minor religious movements took place in West Estonia in the beginning of the 20th century and these regions have maintained certain peculiarities of religious life as compared to the rest of Estonia all through the 20th century.

The aim of the paper is to present a survey of the religious movements and congregations in West Estonia from the 1740s up to the year 1918, when Estonia was part of the Russian Empire. The article also discusses the roots and impact of these movements on the popular culture of the Estonians and Estonian Swedes (the 
Swedes had begun settling on the islands and coast of Western Estonia from the 13th-14th centuries onward). Also, the developments of the religious institutions of West Estonia have been briefly compared to what happened in the religious life of the rest of Estonia and the neighbouring countries. The author has limited himself mainly to Christian congregations and religious movements, although mention is made briefly of the heathen beliefs surviving into the 18th-20th centuries.

\section{OVERVIEW OF RELIGIOUS MOVEMENTS AND CONGREGATIONS IN WEST ESTONIA FROM THE MID-18th TO THE BEGINNING OF THE 20th CENTURY}

The roots of the United Brethren (Moravian, Herrnhuter) movement go back to the 15th-century religious movement of the Bohemian and Moravian brethren, the followers of which founded the Herrnhut community in Germany, in 1722. Count Nikolaus Ludwig von Zinzendorf became head of the Herrnhuter congregation founded in 1727. One of the characteristic features of the Herrnhuter movement was active missionary work. At least 81 missionaries were sent out from Herrnhut in the years $1729-1743$, to awaken Estonian and Latvian peasantry to religion. The peasants accepted the German brethren - simple artisans and teachers, in the most part because they learned the local language and belonged to a lower class than the local German landlords. Nevertheless the success of the Herrnhuter missionaries depended largely on the support of the local Lutheran clergy and landlords. Most of the Herrnhuter missionaries arrived in Estonia after 1738-1739, preparing the ground for the extensive religious awakening that spread among the peasantry at the beginning of the 1740s (see: ILJA 1995).

In North Estonia, the Brethren movement spread widest in Läänemaa and Hiiumaa, where the number of members of the Brethren congregations grew to about 2000, in North Estonia as a whole, the number was about 4800 (ILJA 1995: 240-244). Side by side with Estonians, active part was taken in the religious movements also by the Estonian Swedes. The parishes of Vormsi and Noarootsi in West Estonia, settled mainly by Estonian Swedes, remained the main centres of religious movements in Estonia up to the emigration of Estonian Swedes in the 1940s.

As for South Estonia, Saaremaa rose to a leading position in the Brethren movement, which was led there by the superintendent of the Lutheran Church of Saaremaa, Eberhard Gutsleff junior. Several phenomena alien to the Lutheran Church can be observed in the religious movement of the Saaremaa peasantry, such as the rebaptising of adults and banning work on Thursdays and Saturdays. Prayer meetings lasted for days and nights and saw trembling, dropping down, motionless lying. People had visions and revelations of Christ's bleeding body or hand, of heaven- and hell-travelling, of a heavenly rain of blood; others were soothe-saying prophetically. The Herrnhuters launched a campaign against folk culture, which they declared was heathen. Incidents are recorded of destroying old sacred groves and 
sacrificial sites, as well as of jewellery, festive clothes and folk musical instruments. Alcohol, smoking, dancing and other such worldly pleasures were declared sinister; the same went for stealing and other such crimes (later on, Estonian history books have often operated with the obviously mistaken claim as though not a single crime had been performed in Saaremaa in the years 1740-1745). The same kind of bans and limitations remained characteristic of the Brethren movement later, too. In the 1740s, the number of people involved in the Brethren movement in Läänemaa, Hiiumaa and Saaremaa is estimated at about 5000-6000. In Saaremaa, Herrnhuters constituted about 20-25 per cent of peasantry (RUSSWURM 1855: 159, 283-284; GIRGENSOHN 1869: 453; PÕLDMÄE 1935: 127-128; PHILIPP 1974: 159; ILJA 1995: 240-244, 250).

The Brethren did not set up an independent church in the Baltic, remaining, according to their leaders' whishes, within the framework of the official Lutheran Church. Yet the separatism, open enmity towards the landlords and "religious exaggerations" gave rise to (and offered a pretext for) a growing dissatisfaction with the Brethren among landlords and clergy. In co-operation with authorities, the antiHerrnhuter clergy achieved the banning of the movement with a decree from Empress Elisabeth, in 1743. The Herrnhuters' prayer houses were closed and the more prominent brethren were forced to leave the country. The Lutheran clergymen had to sign a declaration in which they agreed to ban the Herrnhuters' activities in their parishes (HARNACK 1860: 82; PÕLDMÄE 1936: 253; PHILIPP 1974: 162-163, 167; ILJA 1995: 197, 203-204). Yet obeying the orders was not controlled very consistently or effectively, depending largely on the attitude of the local landlords. Despite the bans, new Herrnhut brethren arrived in Estonia and secretly carried on their missionary work. Although the religious movement went underground and had to overcome obstacles and repressions, it continued with relative success in West Estonia. In 1801, there were 4422 members of Brethren congregations in Hiiumaa and Saaremaa (PHILIPP 1974: 388, 410-411), which made up about 11 per cent of peasantry.

The first half of the 19th century witnessed a new rise in the Brethren movement. It was favoured by the decree issued by Tsar Alexander I in 1817, allowing the Brethren congregations freely to pursue their activities, and by the movement of Heaven-Travellers which began to spread during the second decade of the century, mainly within the framework of the Brethren congregations. The centres of the movement of Heaven-Travellers were in Läänemaa and Hiiumaa, where the movement began in 1814. There arose several visionaries and prophets who claimed they had seen revelations and who conducted their own charismatic prayer meetings. The Heaven-Travellers, for the most part women and girls, claimed they had been to heaven and hell. They told whom they had met in heaven or who had been in hell, and foretold people their fate after death. As a result of the Heaven-Travellers' message, the Estonians and Estonian Swedes of Läänemaa burnt their festive dress and jewellery, in order to prepare themselves for the imminent end of the world. The German Moravian J. G. Werner has described how awakened peasants in Noarootsi parish prepared for the end of the World in 1816 burning all their earthly belongings following the orders of a local prophet. Some of the the Heaven-Travellers also 


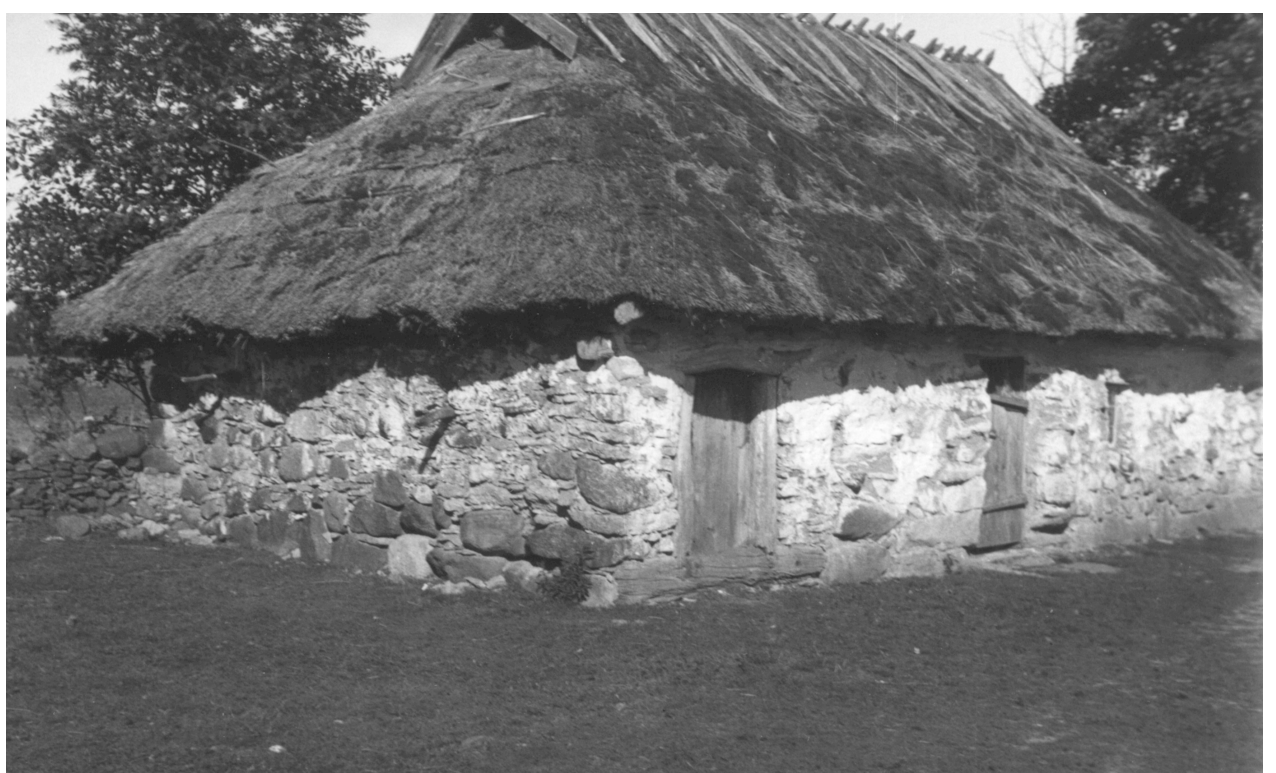

Fig. 1. The chapel of the Brethren congregation in Valjala parish, Saaremaa county, Estonia. Photo by E. Põld, 1938 (Photo Collection of the Estonian National Museum, No. 821: 5)

celebrated Saturday and Thursday. Several prophets from Hiiumaa were accused of baptising each other with fire and smoke and of celebrating the Holy Communion among themselves. Heaven-Travellers and their enthusiastic adherents caused much trouble to the Lutheran pastors and the German Moravians (RUSSWURM 1855: 235236; PÕLDMÄE 1935; 1958: 457-459). In the early 1820s that ecstatic movement gradually died out, but the Brethren congregations in Western Estonia successfully continued their activities.

In the mid-1850s, there were almost 9000 members of Brethren congregations in Läänemaa, Hiiumaa and Saaremaa (constituting 8.6 per cent of the population in Saaremaa), and thousand more participated in the prayer meetings (in Saaremaa, they added up to about 15 per cent of the population). All over Estonia, the approximately 50000 full members of the Brethren congregations made up about 6.7 per cent of the population. In 1839, the number of Brethren prayer houses in Estonia reached 156 (PHILIPP 1974: 219-221, 405-409), which exceeds by one third the number of Lutheran parish churches.

In the middle of the 19th century, the Lutheran Church engaged in active struggle against the Brethren congregations, particularly in South Estonia, and in the second half of the century the movement suffered an internal decline and a great drop in the numbers of membership. The decision of the 1857 Herrnhut Synod to stop direct activities of the Herrnhut centre in the Baltic region certainly played a part in the decline of the movement, too (see also: PHILIPP 1974: 321ff, 368-369).

Another important change in the religious life of West Estonia was the move- 


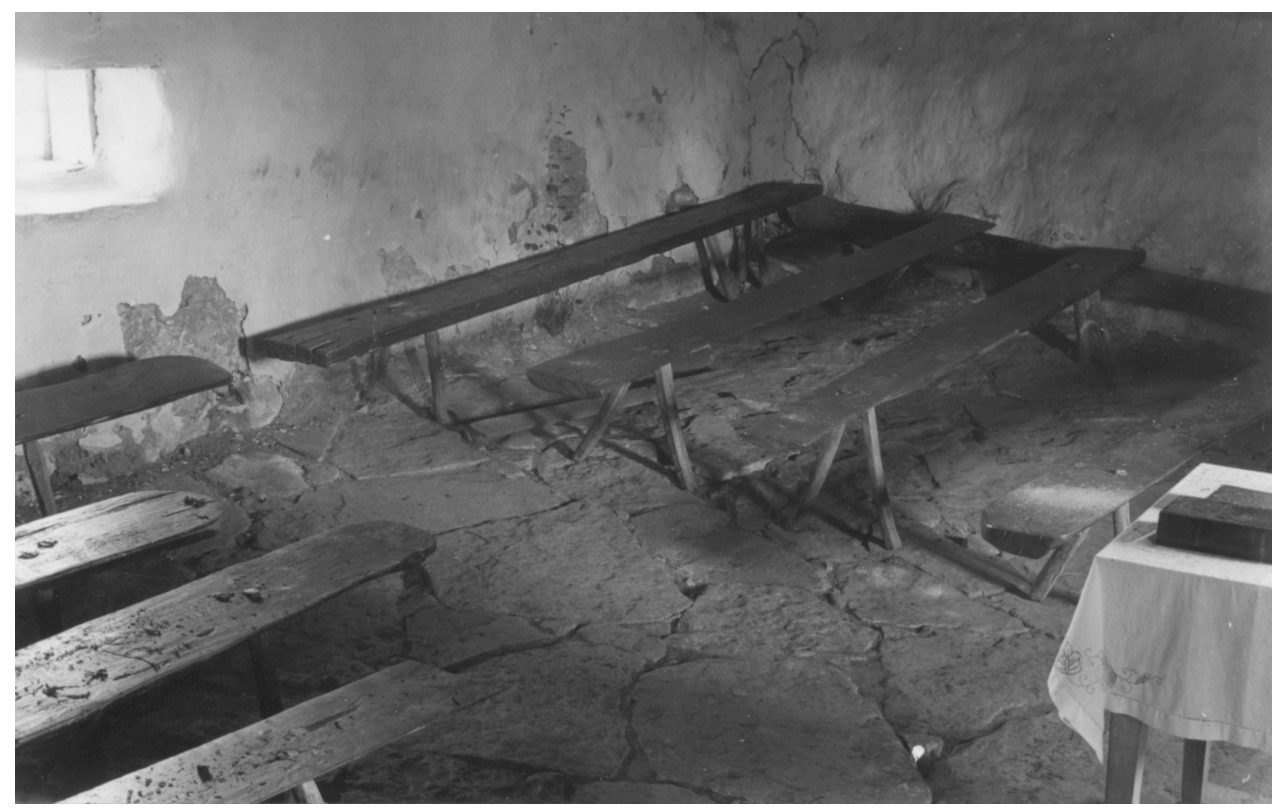

Fig. 2. The prayer room of the chapel of the Brethren congregation in Valjala parish, Saaremaa county, Estonia. Photo by E. Põld, 1938 (Photo Collection of the Estonian National Museum, No. 821: 6)

ment from the Lutheran Church to the Russian Orthodox Church. In the years 18451848, about 17 per cent of South Estonian peasantry transferred their allegiances from Lutheran Church to Orthodox Church, mainly motivated by economic and social hopes. The percentage of those who shifted church was highest in Saaremaa, where by the year 1848, 29.8 per cent of the peasantry had adopted Russian Orthodox faith (KRUUS 1930: 344, 400). After this shift, the Russian Orthodox Church began to build new church buildings and schools for the Estonian peasantry, thus entering into active competition with the Lutheran Church. In the 1880s, the tendency to convert from the Lutheran to the Orthodox Church broke out in North Estonia, with its centres in Läänemaa and Hiiumaa. Tsarist authorities supported the spread of Orthodoxy and took steps against the Lutheran Church, which caused the growth of membership in the 15 Orthodox congregations of Saaremaa up to 40 per cent of the population by the turn of the 19th-20th centuries. In Läänemaa and Hiiumaa, 13.2 per cent of the population were Orthodox in 1897. The census of 1897 reveals that 84.2 per cent of the total population of Estonia were Protestants (mostly Lutherans) whereas 15 per cent were Russian Orthodox or Old Believers (PERVAJA 1905: 122-125; PALLI 1998: 29-31).

To a certain extent, another religious movement which swept over Läänemaa in the 1870s - the Awakening of Läänemaa - was also related to the shifting to Orthodoxy. The Awakening of Läänemaa began with the arrival of two Swedish missionaries, Thure Emanuel Thorén and Lars Johan Österblom. They started working as 
teachers and missionaries in the Noarootsi and Vormsi parishes in 1873 (see: ÖSTERBLOM 1927; VALENTIN 1938: 40ff). In the 1870s-1880s, the new religious awakening began to spread among the Estonian Swedes and then among the Estonians, too. People began to strive for a salvation of their souls and were "saved". In new religious communities there also occurred several ecstatic practices, such as jumping, dancing, laughing and hand-clapping at the prayer meetings (SCHULTZ 1880: 580-581; Protokoll 1883: 5, 1884: 6; OSTERBLOM 1885: 39-43; NORMANN 1885: 113; BUSCH 1928: 32).

At the beginning of the 1880s, many converts in Läänemaa and Hiiumaa started to hold their own communion, baptism, wedding ceremonies and funeral services. The attitude of the Lutheran officials toward the movement had been more or less favourable at the beginning, but it became very hostile as soon as the converts started to secede from the Lutheran Church, which first happened in Vormsi, in 1880. One of the main reasons for that was the immorality and lack of real faith among the members of the Lutheran congregations (Protokoll 1881: 5-6; SPINDLER 1893: 156-157, 161; BUSCH 1928: 28-29).

The persecution by the secular authorities and Lutheran Church grew more vigorous, and the movement dispersed into different factions. The awakened people organised the first Baptist, Irvingite and Free Believers' congregations in Estonia. Many converts accepted the Orthodox faith in the 1880s. In the cradle of the awakening movement of Läänemaa, for instance - on Vormsi Island, more than 500 people or one fourth of the island's population converted to Orthodoxy in the 1880s, despite the fact that the Estonian Swedes of Vormsi did not understand the Russian language at all (Protokoll 1884: 6-7, 1885: 7; Istoriko-statistitsheskoje 1895: 540; Iz Arhiva 1910: 39ff.). Many converts also lost their intense religious feelings or remained faithful to the Lutheran Church and to the Brethren congregations under the Lutheran Church.

Up to the end of the 19th century, the most influential of the new congregations were the illegal Free Believers' communities. The Free Believers' movement also spread from Hiiumaa to Saaremaa county at the end of the 19th century. Several other confessions previously unknown in Estonia also began to spread among the West Estonians at the end of the 19th and beginning of 20th centuries. In Saaremaa, the Methodists gained particularly great support. The first Methodist congregation in Estonia was founded there in 1910 (see: RITSBEK 1996). Since the beginning of the 20th century, the Baptists have been the most influential among the new congregations in West Estonia.

Religious life outside the Lutheran Church in West Estonia remained active during the period of the Estonian Republic (1918-1940) and also during the period of the Soviet occupation in Estonia from the 1940s, despite the atheistic policy of Soviet authorities and rapid process of secularization, especially when comparing to the other regions of Estonia. 


\section{THE ROOTS OF THE RELIGIOUS MOVEMENTS AND THEIR IMPACT ON THE POPULAR CULTURE}

There are several important factors that assisted or may have assisted in the arising and fast spreading of new outbursts of religiousness in West Estonia in the 18 th and 19th centuries. Among these factors figures the poverty of the peasants, as well as the relative backwardness of schools and secular social life. Economic backwardness is most conspicuous in the coastal and island regions of West Estonia. All the greatest outbursts of religious feelings, however, occurred in the poorer coastal parishes. Next, the importance of (socio-) psychological factors in the broad and ecstatic spread of religious movements must be emphasised, as well as the role of leaders, both of local and foreign origin, in the arising and development of the movements.

We must also consider the connections of the religious movements of the counties of West Estonia and Estonia as a whole with the trends of religious life spreading in the neighbouring countries. Usually, the Christian religious movements in Estonia in the 18th and 19th centuries did not originate among the local peasantry but got at least the initial impact from outside Estonia. Foreign missionaries played an important role in the starting of the religious movements. Both the German Herrnhuters and the Swedish missionaries who started the Awakening of Läänemaa arrived from abroad. A certain role in the conversion of Estonian and Estonian Swedish peasants into Russian Orthodoxy was played by Russian clergy. The religious movements taking place elsewhere also help to understand better the trends of development of the West Estonian religious movements during the period of their organisation into different Free Churches, in the last quarter of the 19th and beginning of the 20th centuries. At that time, various Protestant awakening movements and Free Churches were winning broader support in the Baltic guberniyas and Russia's European territories, as well as in the Lutheran countries of Scandinavia and elsewhere in the world (see: AMBURGER 1961; KLIBANOV 1965; NIKOLSKI 1988; HOPE 1995). In the last quarter of the 19th and beginning of 20th centuries, some of these religious movements and Free Churches reached not only West Estonia, but other parts of Estonia, too, mainly through the activities of foreign missionaries.

In their further development, the West Estonian religious movements acquired several characteristic features, too, especially the movement of the HeavenTravellers and those of the last quarter of the 19th century. Thus, for instance, the religious awakening movement of Läänemaa features dancing in prayer meetings as a peculiarity, whereas in Hiiumaa, at the beginning of the 20th century, people acted the roles of different animals at prayer meetings. The rituals that gave rise to the name "vat-worshippers", that is, rituals where a vat was used for baptism or communion, also appear to be originally West Estonian. Uncommon are also efforts to "hatch out the God", to fly to the Heaven (together with a cow), going around naked, hunting the Devil all over the walls, stuffing the Bible into an oven and even attempts to offer people in burnt sacrifice (EAA, f 1249, n 1, s 77, 1140; Walgus, No. 5, 1884, No. 37, 1885; Saarlane, No. 25, 1887; Olewik, No. 36, 1902; OsterblOM 
1885: 40-44; KõPP 1926: 83). Yet, reports of such phenomena are frequently unreliable, just like stories about the custom of exchanging shirts or about sexual rites practised by the awakened. Even the extreme phenomena in the awakening movements, however, are not fully incredible in the light of reports about similar awakening movements elsewhere in the world. Essentially, the Estonian religious awakening movements of the 18th and 19th centuries were not much different from analogous movements elsewhere in Europe.

One of the main reasons why religious movements spread so rapidly and new Free Churches sprang up was the remoteness from the people of the Lutheran Church. Up to the founding of the independent Republic of Estonia in 1918, the overwhelming majority of Lutheran pastors were of German origin (see: SAARD 2000). The predominance of Germans was also supported by advowson, followed in most congregations, which forbade these congregations to choose a suitable pastor for themselves and forced them to accept the one chosen by the landlord and patron. Too large congregations also constituted a major drawback of the Lutheran "landlords' church". Unlike several popular religious movements and Free Churches, the official Church was not able to satisfy fully the people's religious needs. The language and turns of speech used by the peasant preachers in the prayer house must have been much better understood by the people than the sermon made by the Lutheran pastor. Probably one of the main secrets of the success of the awakening movements discussed above was in the emotional approach to religion and a more easily understandable message which the Lutheran Church could not offer. The persecution by the Lutheran Church of the awakened believers often only reinforced the convictions of those who had suffered for their faith and frequently caused hostility towards the Lutheran Church.

In the Estonian congregations of the Russian Orthodox Church, however, most of the priests were Estonians by the beginning of the 20th century (Postimees, No. 45-46, 1910). The Tsar's manifesto of 1905 in principle brought about religious tolerance, which was followed by an upsurge in the activities of the Free Churches and a small-scale re-conversion of Orthodox Estonians into the Lutheran Church. According to the census of 1922, the proportion of the Orthodox had grown to 19 per cent of the population of the Estonian Republic, a development mainly due to the annexing of basically Orthodox territories. 78.6 per cent of the population were registered as Lutheran (Rahva demograafiline 1924: 50). But neither the Lutheran nor the Orthodox Church was able to bring Christian teaching close to the Estonians and Estonian Swedes.

Perhaps it is only during the culmination of the Brethren movement that we can speak about a broader spread of the intense Christianity with really devoted adherents all over Estonia. At the same time we must not forget that only a minor part of the population was directly involved in the Brethren movement in the 18th and 19th centuries, amounting to no more than one tenth of the population even during its highest peak in the middle of the 19th century. Frequently this minority was also in opposition to the greater part of population who had not experienced religious awakening. No other Christian movements of comparable dimensions, covering all 


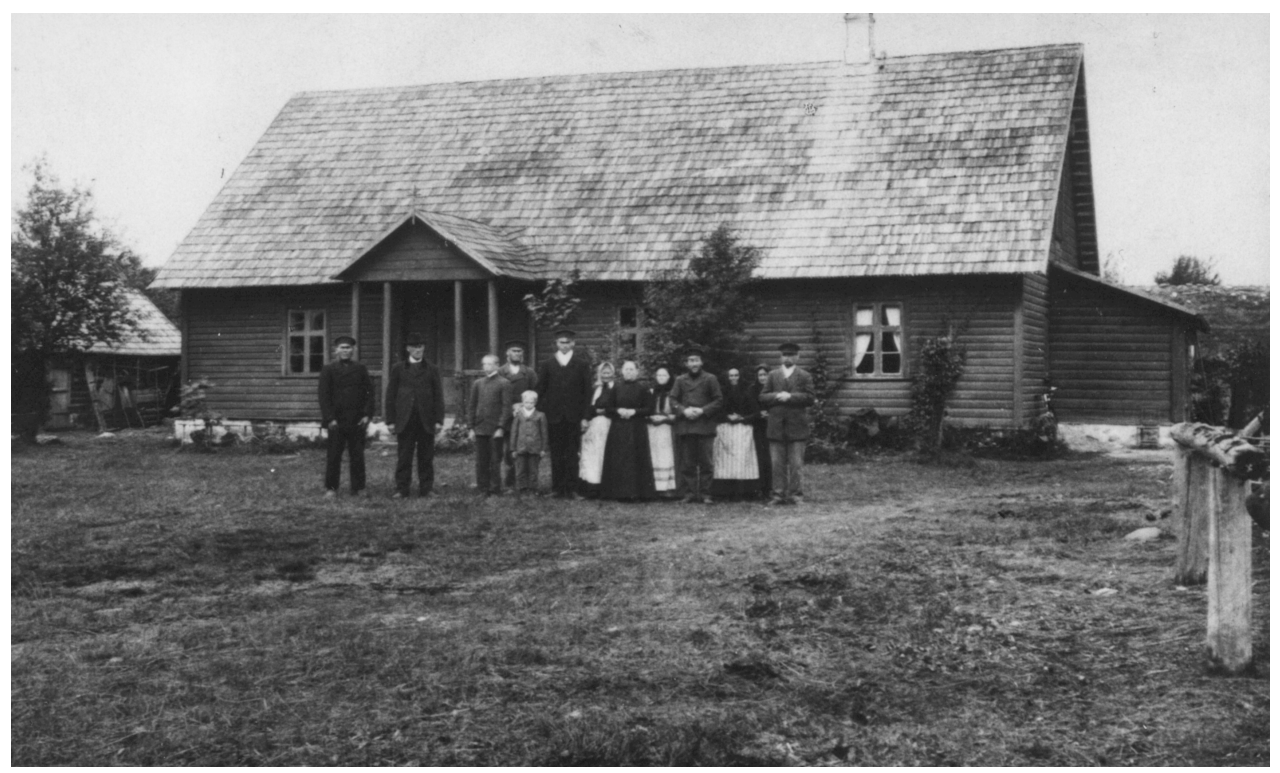

Fig. 3. The prayer house in West Estonia. Photo by M. Rukki, 1913 (Photo Collection of the Estonian National Museum, No. 1347: 40)

of Estonia, have occurred in Estonia after the decline of the Brethren movement. Since the Lutheran and Orthodox Churches remained remote of the Estonian peasantry and the percentage of Free Church members was low, there was actually no reason up to the 20th century to speak about a more serious adherence of Estonians to any Christian confession. The religious life of the 20th century, however, can rather be characterised with the word "secularisation" than "Christianity". The answer to the question whether Christianity has ever been widely accepted in Estonia at all is rather in the negative than in the positive.

Several researchers also consider it possible to view the Brethren movement of the 18th-19th centuries as the first national movement of the Estonian peasantry or at least as a phenomenon preparing ground for such a movement (ILJA 1995: 237; PHILIPP 1974: 367). This view seems actually to be born out by the educational and literary activities, song production and starting of choirs by brethren with peasant origins. The Brethren societies were the first peasant organisations where it was possible freely to pursue collective activities without the direct intervention of landlords. Social emancipation and the growth of awareness among peasants was further promoted by involving numerous Estonian laymen and women in the supervising of congregations, by building prayer houses for funds collected from voluntary donations next to the official Lutheran churches, etc.

Yet it is obviously rash to regard the Brethren movement as a kind of national awakening or even a preparation for it. The main aim of the movement was still to awaken the country-folk religiously, to become the people of Jesus, not the people of 
Estonia. A brother was an awakened peasant, a German Herrnhuter, even a Herrnhuter landlord, not an un-awakened peasant from the farmstead next door. The Herrnhuters were not note-worthily connected with the National Awakening movement that spread in Estonia during the second half of the 19th century and even worked against it. For those who had awakened, the line between "us" and "others" did not run so much by national or even social boundaries as according to the depth of faith, in places even according to membership in one certain congregation. But it was first and foremost the Herrnhuters, not ordinary Lutherans, who were considered deeply religious.

The influence of the Brethren congregations was highest in the West Estonian counties. But the difference of religious life of West Estonia from the rest of Estonia stands out more clearly in connection with the religious movements of the last quarter of the 19th century. If the earlier movements of the Brethren congregations and the Heaven-Travellers spread wider not only in West Estonia, but elsewhere in the country, too, this was not the case with the religious movements of the last quarter of the 19th century. It was the movement of National Awakening that spread at that time in the other Estonian counties; in Läänemaa, Hiiumaa and Saaremaa, however, it met with the least enthusiastic reception.

At the end of the 19th century, the activists of new religious movements took a hostile attitude towards popular culture, because of which old beliefs, folk tales and practices were suppressed and forgotten. The Awakening of Läänemaa and preaching of new prophets caused destruction of various phenomena of the old popular culture of the Estonians and Estonian Swedes. In several regions of West Estonia colorful national costumes, national music and music instruments, popular songs and dances, folk religion and sorcery were considered to be sinful by the "Children of God". For example, in 1870s missionary Lars Johan Österblom declared the folk songs, dances and costumes of the Estonian Swedes of Vormsi Island and Thure Emanuel Thorén the dances of Noarootsi parish to be sinful (BUSCH 1928: 12). Several Swedish authors (DANELl 1909; WENNERSTRÖM 1931) have also stressed that Österblom did not tolerate old folk culture and that sense of national identity of the Estonian Swedes weakened because of his missionary work, as all the Swedes and stonians had to become brothers and sisters disregarding their nationality.

The revivalist movements in West Estonia have also changed the local folklore. Estonian folklorist Oskar LOORITS claimed that the Moravian movement was so influential in West Estonia that it partly wiped out old folk songs and stories, replacing them with prayers, religious songs and stories about local prophets (LOORITS 1932: 39). Another Estonian folklorist Rudolf PÕLDMÄE also mentioned that West Estonia abounds in stories about prophets, heaven-travellers, revelations, spirits and everything supernatural (PÕLDMÄE 1938: 439). Some prophecies of the West Estonian 19-century prophets have been believed in up to the 20th century.

At least among the converts of the Awakening of Läänemaa new religious songs replaced the old ones. The so called Swedish songs, brought by missionaries Thorén and Österblom were soon translated into Estonian and became part of repertory of 
Baptists and Free congregations (Eesti Postimees, No. 29, 1881; Walgus, No. 5, 1884; OSTERBLOM 1885: 50; EKM, KO, f47, m 41:33, 11/7).

While the revivalist movements fought old popular culture, many features in these revivalist movements seem to suggest that the rituals and beliefs of converts were also influenced by folk beliefs and the profane. Some authors claim that in many centers of the revivalist movements in Läänemaa and Saaremaa, the pagan beliefs have been successfully preserved up to the beginning of the 20th century (Eesti Postimees, No. 26, 1884; Wirulane, No. 24, 1884; Saarlane, No. 38, 1896; No. 3, 1897; No. 2, 10, 1900; Olewik, No. 55, 1905, p. 871; MARTNA 1914: 122-124). In the last decades of the 19th and beginning of 20th centuries, there existed a rich heritage of older popular beliefs and practices in West Estonia. They existed there together with the popular forms of Christianity spread by different confessions, occasionally intertwining and influencing each other. Therefore it would not be correct to speak about the complete havoc wrought at traditional religion by the earlier Christian religious movements, just like the reports of the complete victory of the religiously awakened over folk musical instruments, clothes, dances, drinking, crime and other "sins" at the highest moments of various religious movements are, as a rule, exaggerated.

The revivalist movements also changed the attitudes of converts towards nonbelievers, as well as towards secular education and literature, government, state and laws, which were sometimes considered by believers to come from the Devil. Several illegal Free Believers' congregations claimed that they did not need official permission from the Lutheran Church and secular authorities for their activities. They ignored several earthly laws and felt themselves free in performing their rituals and forming their belief system. Some converts believed that the only power they have to ask for permission is Jesus. Others refused to pay taxes and neglected orders of police or court. In several places of West Estonia conflicts between converts and local masters, court officials and Lutheran pastors arose. Some converts also claimed that Lutheran schools and school teachers had come from the Devil and did not send their children to schools where educated pagans were brought up. Several new congregations, especially the Baptist and Free Believers' congregations, started to teach the children of their members by themselves (EAA, f29, n 2, s 5480, 1 148-150; EKM, KO, f 47, m 27:19; SCHULTZ 1880: 581-582; Walgus, No. 26, 1884; NORMANN 1885: 107-108, 113; Iz Arhiva 1910: 86-87; KÕPP 1926: 83).

Many converts in the 1870 s and 1880 s started to despise all the non-believers and members of the Lutheran Church and considered themselves to be the only real believers, the saved and holy people. All the outsiders were labeled children of Devil and many "Children of God" gave up all relationship with old friends and relatives who had not experienced awakening (Protokoll 1882: 6; Eesti Postimees, No. 6, 1884, No. 8, 1889; EAA, f 1278, n 1, s 28, 16, 16p; LindENBERG 1891: 490; KURRIKOFF 1894: No. 102). This change in attitude was caused partly by the several forms of repressions by the local people, who were not converted. The converts were frequently mocked at, beaten and threatened to be killed (Teekäija, No. 7, 1925; TUTTAR-DAHL 1929: 75; EAA, f 1278, n 1, s 28, 1 6). In some pieces of folklore from 
West Estonia the saved people have also been ridiculed (see: Kelle 1963). At the same time the preachers and missionaries of the awakened people tried to save the sinful souls through their active missionary work all over the West Estonia, other parts of Estonia and even in Russia.

The every-day life of awakened peasants also began to differ considerably from the life of their "sinful" neighbors. Many converts of the Awakening of Läänemaa strove for more moral life, and thus abandoned drinking, smoking and theft. For example, in Noarootsi parish in Läänemaa many peasants, afraid of torments of Hell, abandoned drinking, smoking and dancing (Protokoll 1876: 23; Kristlik Perekonna leht, No. 11, 1923, p. 162). Missionary Österblom has written that drinking, dirty language, smoking and other sins disappeared almost completely from Vormsi island. He maintained that the whole communities have ceremoniously buried their tobacco pipes (ÖsTERBLOM 1927). However, Österblom's description of his own success cannot be relied upon uncritically.

We can conclude, that the main revivalist movements in West Estonia - the Moravian movement since 1740s, movement of Heaven-Travellers and Awakening of Läänemaa since 1870s, - have caused changes not only in the lives of the awakened Estonians and Estonian Swedes but also in the cultural and social life of the involved peasant communities. The above mentioned changes influenced the old folk culture, religious beliefs and everyday life of peasantry. But at the same time the converts became somewhat isolated from the mundane and their "sinful" neighbors. The direct and long-lasting impact of the religious movements was confined rather to people involved in these movements than to the West Estonian peasantry as a whole. At the same time, the popular culture had also some influence on peasant revivalism. One of the main consequences of the religious movements in West Estonia was the creation of serious alternatives to the Lutheran Church.

\title{
ARCHIVE COLLECTIONS
}

EAA $=$ Eesti Ajalooarhiiv (Estonian Archive of History, Tartu)

$\mathrm{EKM}=$ Eesti Kirjandusmuuseum (Estonian Museum of Literature, Tartu)

Estonian newspapers of the 19th-20th centuries in the Estonian Museum of Literature (Eesti Postimees, Kristlik Perekonna leht, Olewik, Postimees, Saarlane, Teekäija Walgus, Wirulane).

\section{LITERATURE}

\author{
AMBURGER, Erik \\ 1961: Geschichte des Protestantismus in Russland. Stuttgart. \\ BusCH, M \\ 1928: Ridala ärkamise ajalugu. (The Awakening of Ridala Parish in Läänemaa.) Keila. \\ DANELL, Gideon \\ 1909: Baltiska svenskar I. (The Baltic Swedish I.) - Årsbok 1909. Göteborg, s. 3-34.
}


GIRGENSOHN, Reinhold

1869: Eberhard Gutsleff. - Dorpater Zeitschrift für Theologie und Kirche 1.4: 423-504.

HOPE, Nicholas

1995: German and Scandinavian Protestantism 1700-1918. Oxford History of the Christian Church. Oxford.

ILJA, Voldemar

1995: Vennastekoguduse (herrnhutluse) ajalugu Eestimaal (Põhja-Eesti) 1730-1743. (The History of Fraternity of the Moravian Brethren (Herrnhuter) in Estonia (North-Estonia) 1730-1743.) Tallinn.

Istoriko-statistitsheskoje = Историко-статистическое описание церквей и приходов Рижской епархии. Рижския Епархиальния Ведомости 9: 494-510. Рига 1895.

Iz Arhiva = Из архива князя С. В. Шаховского III. Санкт-Петербург 1910.

Kelle $=\quad$ Kelle peale sa loodad. Valimik usu ja kiriku vastaseid rahvaluuletekste. (Collection of Folklore Texts Against Religion and Church.) Eds. S. LÄTT-Ingrid RüÜTEL. Tallinn 1963.

KLIBANOV, Aleksander

1965: Клибанов, Александр: История религиозного сектантства в России (60-е годы ХІХ в.-1917 г.). Москва.

KRUUS, Hans

1930: Talurahva käärimine Lõuna-Eestis XIX sajandi 40.-ndail aastail. (The Fermentation of the Peasantry in South Estonia in the 1840s.) Tartu.

KURRIKOFF, Andreas

1894: Läänemaa vaimulik liikumine. (Spiritual Movement in Läänemaa.) - Postimees, pp. 100106.

KõPP, Johan

1926: Usulisi liikumisi Eestis. (Religious Movements in Estonia.) Tartu.

LINDENBERG, Jakov

1891: Линденберг, Яков: Протестантские секты в Прибалтийском крае. - Рижския Епархиальния Ведомости 9. Рига.

LOORITS, Oskar

1932: Vanavara kultuuriloo teenistusse! (The Use of Old Material Culture in Cultural History) Opetatud Eesti Seltsi Kirjad 1: 35-58. (The Letters of Estonian Learned Society 1.) Tartu.

MARTNA, Mihkel

1914: Külast, Mälestused ja tähelepanekud Eesti külaelu arenemisest pärast 60-id aastaid. (About Village. Memories and Notes of the Development of Village Life after 60s). Tallinn.

NIKOLSKI, Nikolai

1988: Vene kiriku ajalugu. (The History of the Russian Church.) Tallinn.

NORMANN, Paul

1885: Die geistliche Bewegung im Kirchspiel Pühhalep. - Mittheilungen und Nachrichten für die evangelische Kirche in Russland 41: 106-117.

OSTERBLOM, J.

1885: Остерблом, Ю.: Новейшія религіозныя движенія въ Эстляндіи. Санкт-Петербург.

ÖSTERBLOM, Lars Johan

1927: Svenskarna i Östersjöprovinserna. Karlshamn.

PALLI, Heldur

1998: Eesti rahvastiku ajaloo lühiülevaade. (The Brief Overview of the History of the Estonian Population.) Tallinn.

Pеrvaja = Первая всеобщая перепис населения Российской Империи, 1897 г. Ред. Н. А. Тройницкий. Том. XLIX. Эстляндская губерния. Санкт-Петербург 1905.

PHILIPP, Guntram

1974: Die Wirksamkeit der herrnhuter Brüdergemeinde unter den Estonia und Letten zur Zeit der Bauernbefreiung. Köln, Wien.

Protokoll = Protokoll der Ehstländischen Provinzial-Synode vom Jahre 1876, 1881-1885.

PÕLDMÄE, Rudolf

1935: Taevakäijad. (The Heaven-Travellers.) - Õpetatud Eesti Seltsi Kirjad (The Letters of Estonian Learned Society 3.) Tartu, pp. 123-176.

1936: Eesti vennastekoguduse kirjandusest XVIII sajandi keskel. (About the Literature of Brethren Congregation in the Middle of 18th Century) - Eesti Kirjandus 6: 249-269, 7: 324-343.

1938: Rahvaluulekorjaja tööradadelt. (Collecting Folklore.) - Eesti Kirjandus 10: 433-445. 
PÕLDMÄE, Rudolf

1958: Etnograafilisi ja olustikulisi andmeid vennastekoguduse allikais. (Ethnographic Data in the Sources about Brethren Congregations.) - in the Archive of the Estonian National Museum: ERM, EA V II: 385-481.

Rahva demograafiline = Rahva demograafiline koosseis ja korteriolud Eestis. 1922 a. üldrahvalugemise andmed. Vihk I. (The Demographic Composition and Housing Conditions in Estonia. The Data of the 1922 Census. No. I.) Tallinn 1924.

RITSBEK, Heigo

1996: The Mission of Methodism in Estonia. Boston.

RusswURM, Carl

1855: Eibofolke oder die Schweden an den Küsten Ehstlands und auf Runö II. Reval.

SAARD, Riho

2000: Eesti rahvusest luterliku pastorkonna väljakujunemine ja vaba rahvakiriku projekti loomine, 1870 1917. (The Formation of a Lutheran Clergy of Estonian Descent and the Establishment of a Programme for a Free People's Church, 1870-1917.) Suomen kirkkohistoriallisen seuran toimituksia 184. Helsinki.

SCHULTZ, Woldemar

1880: Die neue Bewegung unter dem ehstländischen Landvolk. - Baltische Monatsschrift 27. 7: 579588.

SPINDLER, Hermann

1893: Ueber das Sectenwesen in Röthel. - Mittheilungen und Nachrichten für die evangelische Kirche in Russland 49: 145-167.

TUTTAR, Hindrek-DAHL, Harald Victor

1929: Ärkamise aeg. Eesti baptismi ajalugu I. (The Times of Awakening. History of Estonian Baptism I.) Tallinn.

VALENTIN, Aron

1938: Svensk-Estlands apostel. Stockholm.

WENNERSTRÖM, Thorsten

1931: Svenskarna i Finland och Estland. Göteborg. 